\title{
Symptoms, Etiology and Disease Cycle of Apple Scab in Harsil, Gangotri Fruit Belt, Uttarakhand, India
}

\author{
R. K. Prasad $^{1 *}$, K. P. Singh ${ }^{2}$, R. K. Gupta ${ }^{3}$ and J. Kumar ${ }^{2}$ \\ ${ }^{1}$ Plant Pathology Section, College of Forestry Ranichauri Tehri Garhwal, 249 199, \\ Uttarakhand, India \\ ${ }^{2}$ Department of Plant Pathology, GBPUA\&T, Pantnagar U.S Nagar, Uttarakhand, India \\ ${ }^{3}$ Department of Botany, BHU, Varanasi, U.P., India \\ *Corresponding author
}

\section{Keywords}

Apple Scab, Symptoms,

Etiology and

Disease Cycle

Article Info

Accepted:

25 October 2018

Available Online:

10 November 2018

\section{A B S T R A C T}

Scab is the most serious disease of apple, particularly in years with cool wet springs and summers. Symptoms occur on leaf blade, fruit, petioles, sepals, blossoms, young shoots, and bud scales. The lesion increase in size as olive green colored which become progressively darker brown raised and velvety in appearance due to the abundant production of conidiophores and conidia. Symptoms are likely to appears on the undersides of new leaves The scab lesions on the lower leaf surface as often extending along the veins and the midrib and appearing diffuse, with irregular, poorly defined borders, thus unlike the discrete, sharply delineated lesions common on the leaf blade. Later, as the leaves unfold, both surfaces are exposed and can become infected. Foliar symptoms that develop in autumn are often quite different in appearance from the olivacious, velvety spot. Occasionally the underlying cells of the lesion turn brown and die, making lesions visible on the both the surfaces. Twig and blossom infection appear as small scab spot, but at most places they are uncommon and of little importance. The lesion appears on the blossom as an olivaceous spot on the calyx. On mature apples, smaller, secondary lesions often develop near a large primary scab lesion. Fruit lesions are usually very small at first, and, compared with leaf lesions, they usually enlarge more slowly, are dark-coloured, and are more sharply bordered. Early infection can kill young meristematic tissue near the fruit surface, which develop unevenly. The fruit shape is also often distorted as a result of early infection. Older lesions become bare, brown, and corky in the center as the fungus dies. The margins remain black, sometime surrounded with a whitish band of loosened cuticle. Scab lesions develop more slowly when infections occur late in the season, and they may not become visible until the apples are in storage. These spots are usually smaller (pin-head or pinpoint scab) sunken black lesions which lack the olivaceous velvety appearance of lesions on young fruit. Imperfect (Asexual) stage and perfect (Sexual) stages of the fungus have been encountered in nature. The perfect or perithecial stage (Venturia inaequalis (cke.) Wint.) Saprophytic, while imperfect or conidial stage (Spilocea pomi Fr.) is parasitic. Venturia inaequalis produces pseudothecia in a stroma in overwintered leaves on the orchard floor. The pseudothecia are negatively geotrophic dark brown to black, globose (90 - $150 \mu \mathrm{m}$ in diameter) amphigenous, scattered grouped, with or without setae and have short beak and a distinct ostiole with single celled bristles at the apex. Conidiophores arise from subcuticular layer of intraepidermal mycelium which forms radiating plates and are simple cylindrical, pale to mid brown to olivaceous-brown, erect, closely septate, sometimes swollen at the base, and variable in length up to $90 \mu \mathrm{m}$ long and 5-6 $\mu \mathrm{m}$ thick. Conidia are produced singly at the tip of a conidiophores and then successively by proliferation through scars of the fallen conidia that result in characteristics and distinct on the conidiophores. 


\section{Introduction}

Scab is the most serious disease of apple, particularly in years with cool wet springs and summers. Apple scab is a fungal disease of the fruit and foliage. Symptoms occur on leaf blade, fruit, petioles, sepals, blossoms, young shoots, and bud scales. The lesion is circular and become covered with numerous darkened lines (mycelium) appear on the upper surface as a lighter shade of green compared with the healthy surface of the leaf. The lesion increase in size as olive green colored which become progressively darker brown raised and velvety in appearance due to the abundant production of conidiophores and conidia. Some spots are nearly black in colour, thus the name 'black spot', which is the more common name for this disease in Australia, Newzeland, and South Africa. Later, the inner portion of a lesion may become brown or gray as the fungus in that portion dies and the leaf tissue underneath is killed. Infections that occur on expanding leaves often cause a slight puckering or blistering effect.

Symptoms are likely to appears on the undersides of new leaves (Clinton, 1901). Leaves unfurl with the midrib as an axis and the upper side facing inward with edges somewhat involutes. Thus the lower surface next to the midrib being the first is most exposed surface. Several workers (Aderhold, 1896; Keitt, 1953; Thakur and $\mathrm{Xu}, 2004$; Thakur and Sharma, 1999; Singh and Kumar, 2005) described scab lesions first appears on the undersides of new leaves as olive green spots which become progressively darker brown raised and velvety in appearance. Later, the velvety surface disappears, the lesions appear metallic black in colour and may be slightly raised. The scab lesions on the lower leaf surface as often extending along the veins and the midrib and appearing diffuse, with irregular, poorly defined borders, thus unlike the discrete, sharply delineated lesions common on the leaf blade. Later, as the leaves unfold, both surfaces are exposed and can become infected.

Foliar symptoms that develop in autumn are often quite different in appearance from the olivacious, velvety spot. The lesions may develop on both surface as small, round spots covered with a tan to dark-brown mycelial growth. These lesions are often numerous and clustered near the margin of the upper or lower leaf surface of flat or cupped leaves, although they may distributed over the entire surface and become obscured as several lesions coalesce. As the infected leaf ages, the tissues adjacent to a lesion thicken, resulting in deformed leaves. Occasionally the underlying cells of the lesion turn brown and die, making lesions visible on the both the surfaces.

Twig and blossom infection appear as small scab spot, but at most places they are uncommon and of little importance. The lesion appears on the blossom as an olivaceous spot on the calyx. Bud or blossom infections commonly lead to shedding of the blossoms or to severe infection of developing fruit, and even blossoms with the lesion seldom remain on the tree. Lesions also develop as olivaceous spots on the pedicel. Blisters are formed on the twigs which contain mycelium and conidia below the ruptured epidermis. Bud scale infection is another source of infection. Sepals are usually the first green orange exposed when buds break in the spring, and because they remain attached until a fruit matures, they are a source of secondary inoculums for developing fruit. The fungus may grow profusely along the main vein and major side veins, with little or no observable growth on the blade. Infected veins appear reddish-brown in color and produces conidiophores and conidia of $V$. inaequalis (Fig. 1). 
Fig.1 Symptoms of apple scab on leaves. a. mycelial growth along with midrib; b, mycelial growth on lateral veins; c \& d, light-brown sporulating lesions on the upper leaf surface; e. old necrotic lesion showing on old leaves
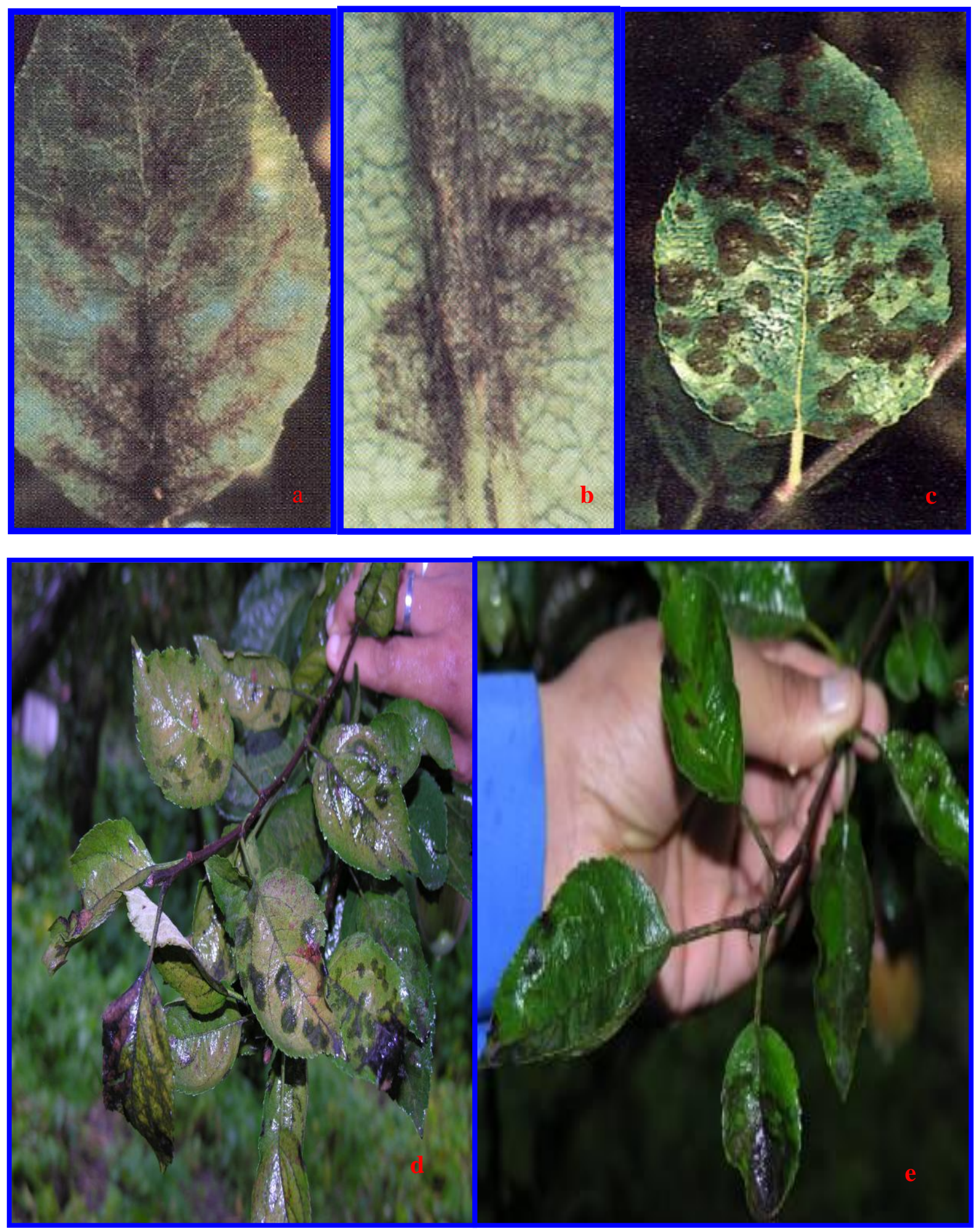
The scab spots are usually more definitely defined on the fruit, which of course very considerably from each other depending upon the time of infection and variety of the fruit invaded. A fruit infected when young, usually becomes deformed, and a fruit may drop when the infected pedicel is girdled. Lesions are most prevalent at the calyx end of an apple early in the season, but by harvest they may be found on any part of an apple. On mature apples, smaller, secondary lesions often develop near a large primary scab lesion. Fruit lesions are usually very small at first, and, compared with leaf lesions, they usually enlarge more slowly, are dark-coloured, and are more sharply bordered. Early infection can kill young meristematic tissue near the fruit surface, which develop unevenly. The fruit shape is also often distorted as a result of early infection. Older lesions become bare, brown, and corky in the center as the fungus dies. The margins remain black, sometime surrounded with a whitish band of loosened cuticle. A scab spot may enlarge and cover a large area of the fruit e.g. over half the fruit, and the fruit may crack due to callus tissue that does not expand as the fruit enlarges. Cracks then appear in the fruit skin and flesh and the fruit may become deformed (Fig. 2).

Scab lesions develop more slowly when infections occur late in the season, and they may not become visible until the apples are in storage. These spots are usually smaller (pinhead or pinpoint scab) sunken black lesions (ink spot), which lack the olivaceous velvety appearance of lesions on young fruit. It is also not unusual for apparently 'near clean' fruit to develop scab spots during storage indicating late infection. This phase of the disease is called storage scab. The most destructive phase is one when the lesions are invaded by other fruit saprophytes and fruits start rotting (Fig. 3).

\section{The pathogen}

Both the imperfect (Asexual) stage and perfect
(Sexual) stages of the fungus have been encountered in nature. The perfect or perithecial stage (Venturia inaequalis (cke.) Wint.) is saprophytic, while imperfect or conidial stage (Spilocea pomi Fr.) is parasitic. It can be cultured in artificial medium. Modified glucose asparagine medium at $\mathrm{pH}$ 6.0 at $20^{\circ} \mathrm{C}$ is best for culture growth and sporulation (Gupta and Lele, 1980). It is suspected that there are two strains existing in Kashmir, one invading cv. Red Delicious is more virulent, and another on cv. Ambari is milder. Himachal Pradesh and Uttarakhand fortunately are suspected to have only race-1 out of five races or strains of the pathogen so far known to occur all over the world.

\section{Perfect state}

Venturia inaequalis produces pseudothecia in a stroma in overwintered leaves on the orchard floor. The pseudothecia are negatively geotrophic dark brown to black, globose (90 $150 \mu \mathrm{m}$ in diameter) amphigenous, scattered grouped, with or without setae and have short beak and a distinct ostiole with single celled bristles at the apex. The centrum is pseudoparenchymatous with pseudoparaphysis. Asci (60-70 x 7-12 $\mu \mathrm{m}$ wide) about 70-100 per pseudothecium, are cylindrical, fusciculate, short- stipitate, and each contain eight spores. The ascus wall is thin and bitunicate. Ascospores (12-15 x 6-8 $\mu \mathrm{m})$ are mono or districhous, olive brown, with ends tapering and lower ends rounded and unequally two celled, with the upper cell shorter and wider than the lower cell. The unequal size of the two cells in the ascospores gives the species its name (Fig. 4).

\section{Imperfect state}

Conidiophores arise from subcuticular layer of intraepidermal mycelium which forms radiating plates and are simple cylindrical, pale to mid brown to olivaceous-brown, erect, closely septate, sometimes swollen at the base, 
and variable in length up to $90 \mu \mathrm{m}$ long and 5$6 \mu \mathrm{m}$ thick. Conidia are produced singly at the tip of a conidiophores and then successively by proliferation through scars of the fallen conidia that result in characteristics and distinct annellations on the conidiophores.
Conidia are obpyreform to obclavate pale to mid-olivacious brown, smooth, 0.1 septate, and $12-30 \times 6-10 \mu \mathrm{m}$ wide to their broadest part with a truncate base $4-5 \mu \mathrm{m}$ wide (Sivanesan and Waller, 1974) (Fig. 5).

Fig.2 Scab symptoms on different stage of fruit in apple. a, Scab sporulating lesions at the tip of each sepal; b. Olivaceous sporulating lesions at fruit set stage; c. One or several scab lesions at walnut size of fruit; d, Primary and secondary scab lesions on fruit; e, A raised, ridged, cracked, corky scab lesion; f, Late summer scab that have burst to form cracks; g. Several old and young (dark, olivaceous) scab lesions after post-harvest

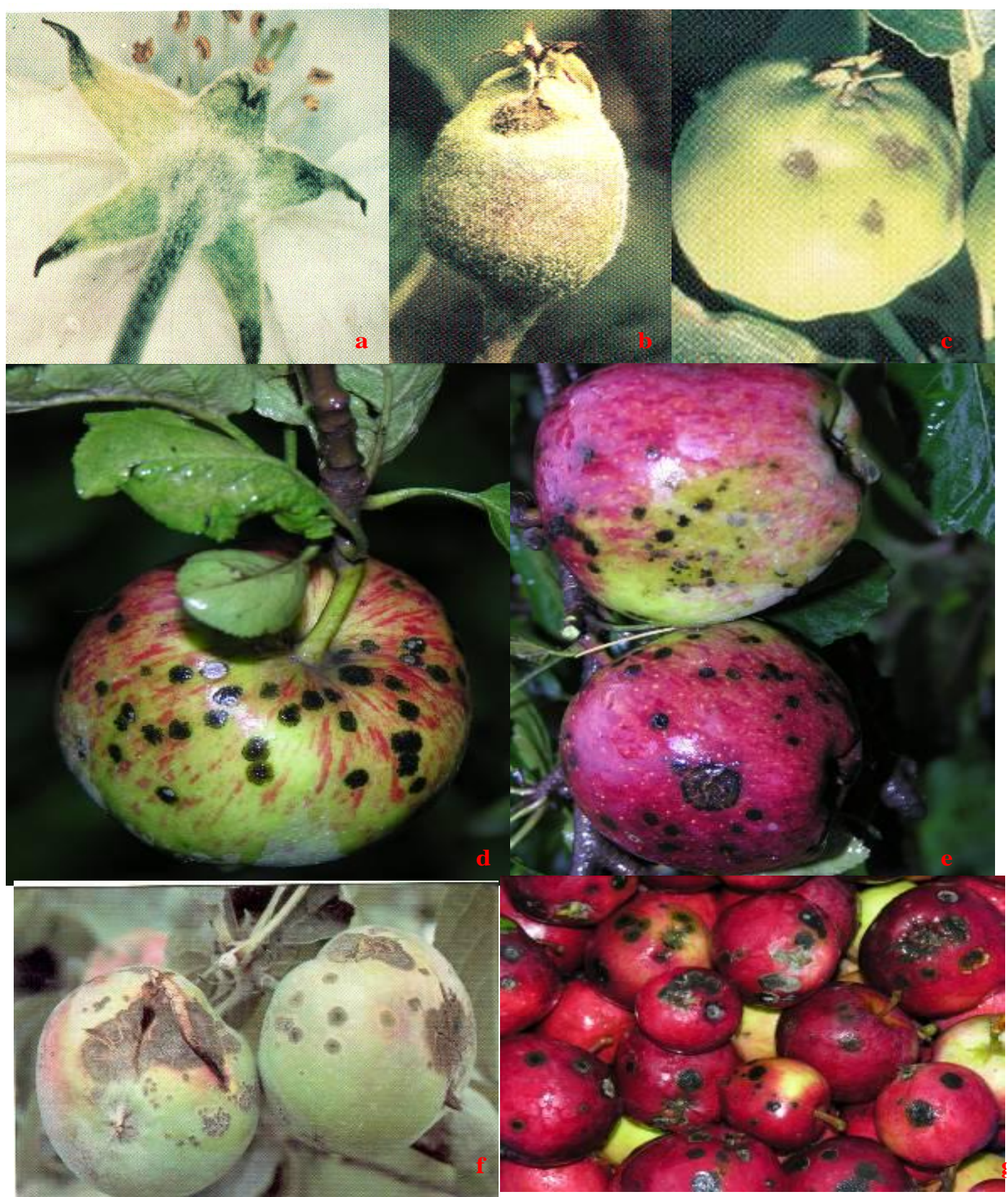


Fig.3 Primary and secondary infection of apple scab. a, Late summer scab lesion on a fruit showing an exposed dark brown whitish sporulating stroma; b. Field view of scab symptoms on leaves and fruit

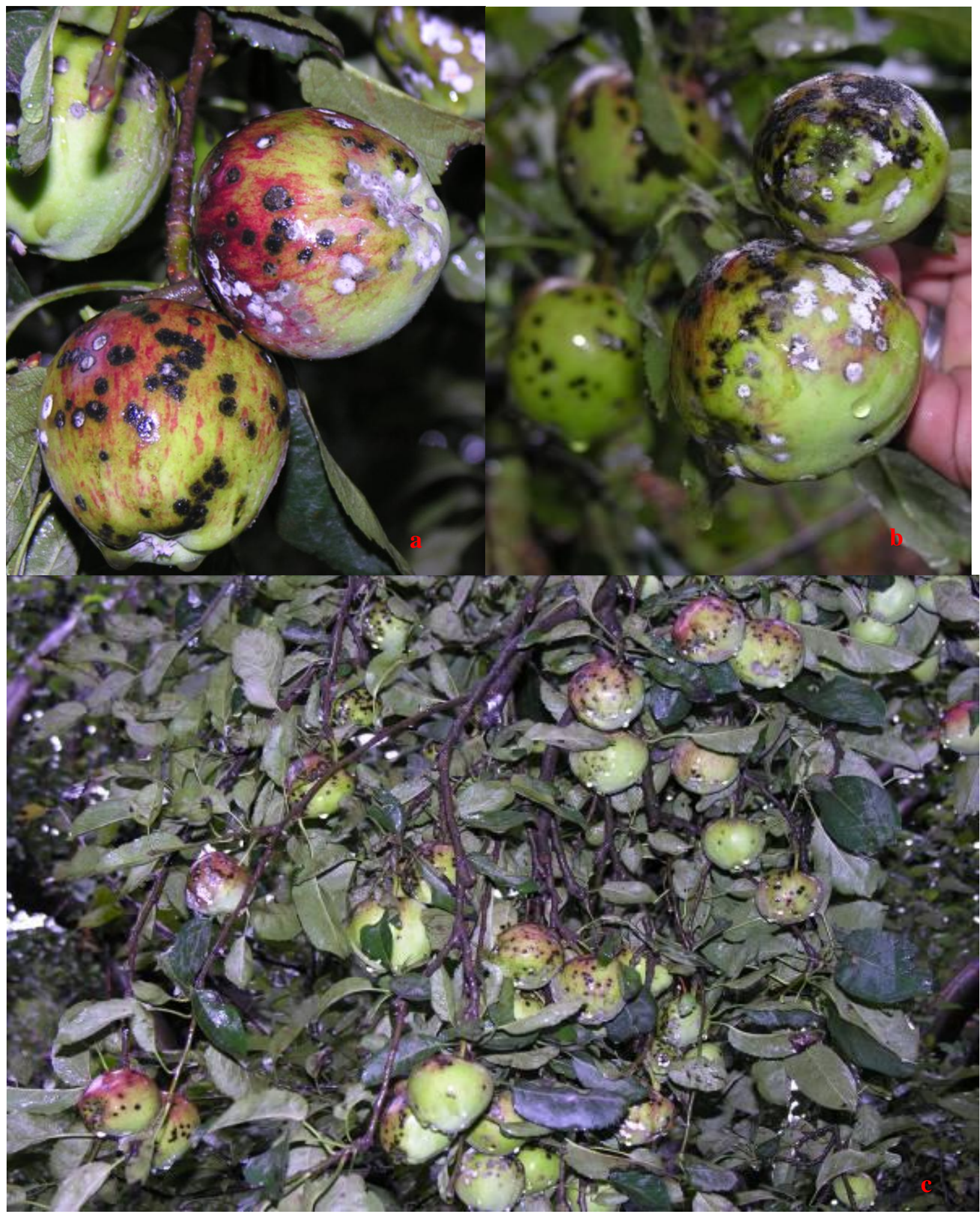


Fig.4 Initiation and development of the pseudothecium and asci of Venturia inaequalis. a \& b, Pseudothecium on overwintered fallen leaves of apple. c \& d, Formation of pseudothecium; e \& $\mathrm{f}$, Matured pseudothecium with asci filled with ascospores

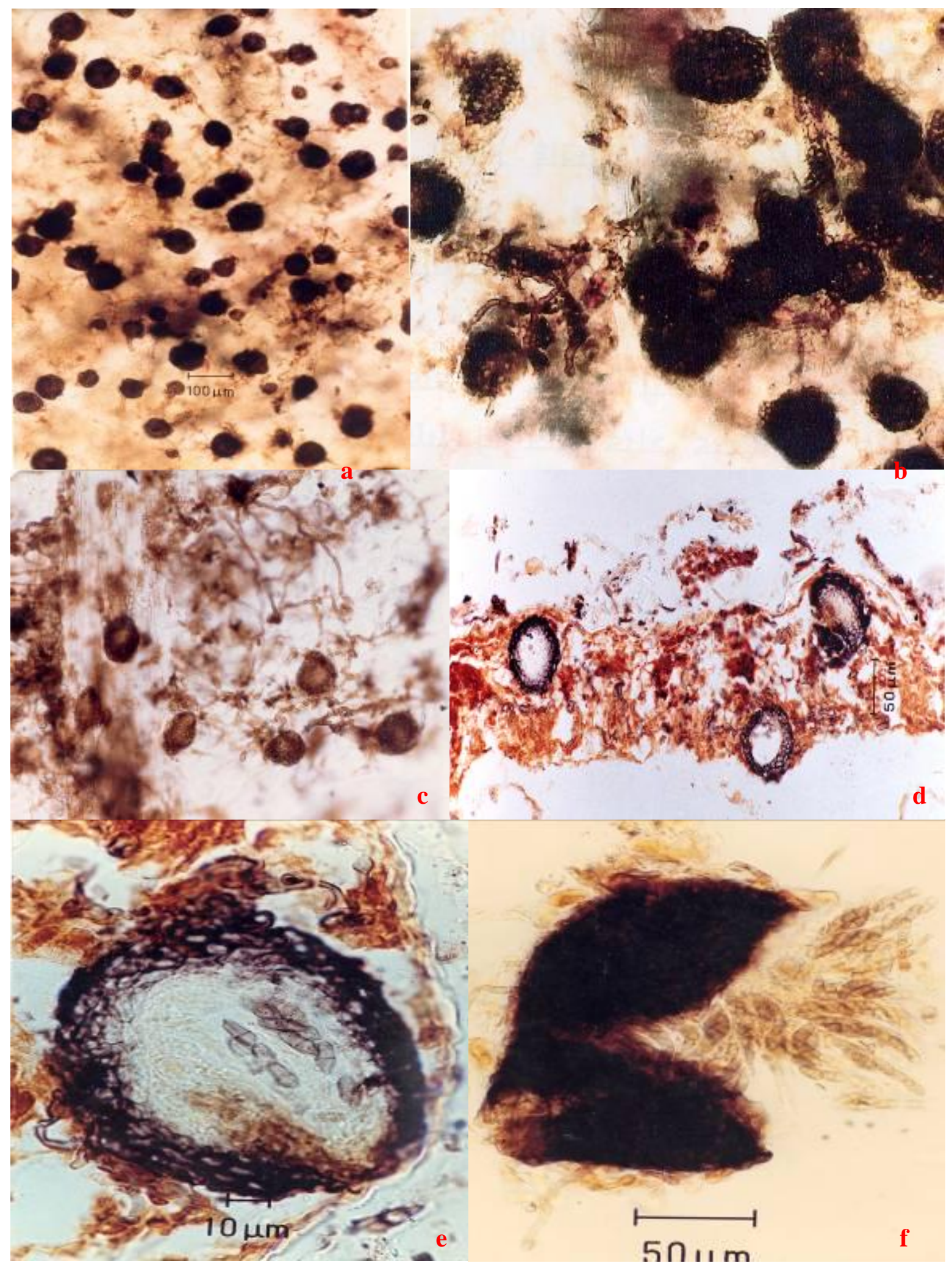


Fig.5 Primary and secondary infective propogules. a, Matured ascus with eight ascospores; b, Secondary infection by conidium till the defoliation

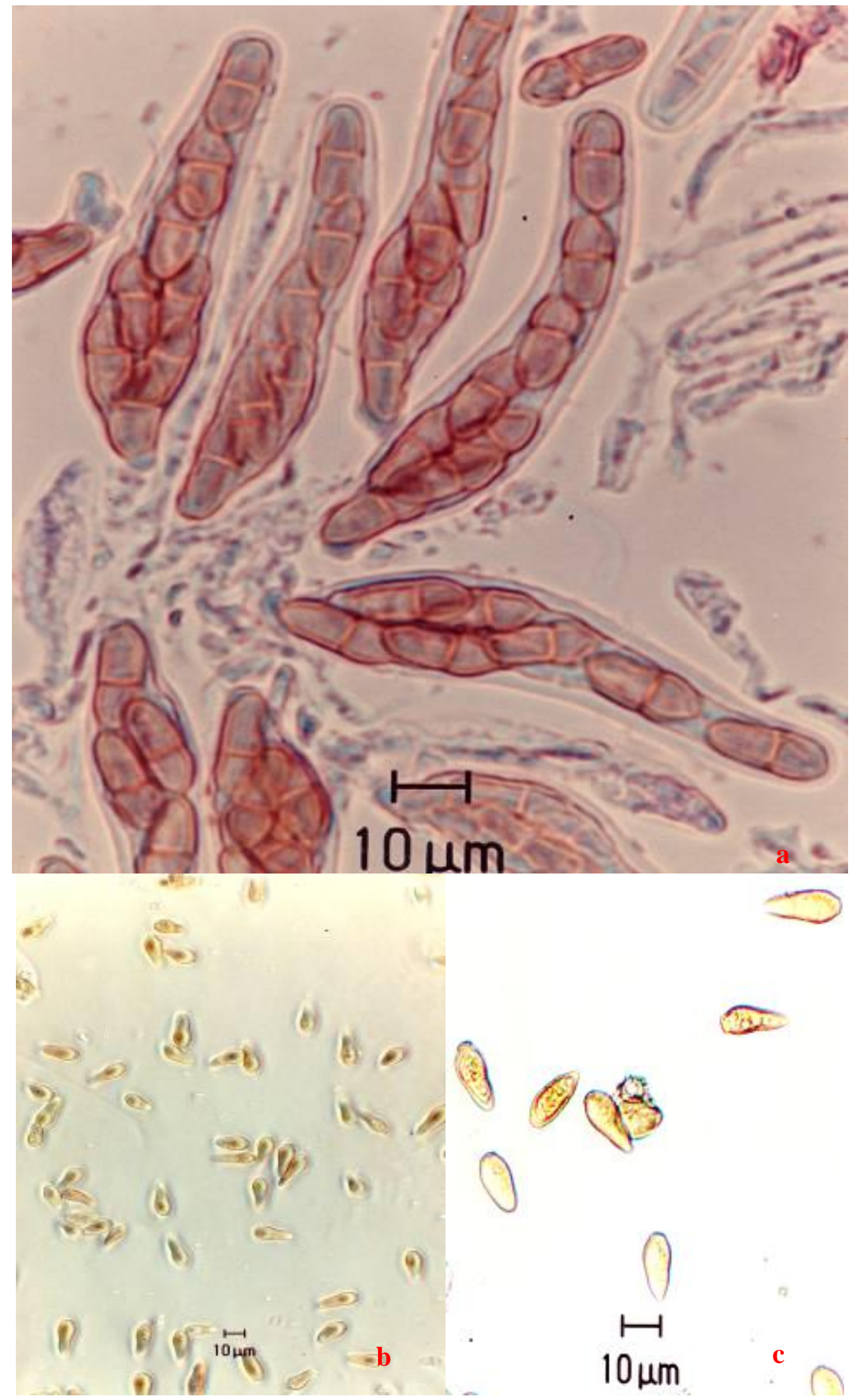


Fig.6 Disease cycle of apple scab fungus

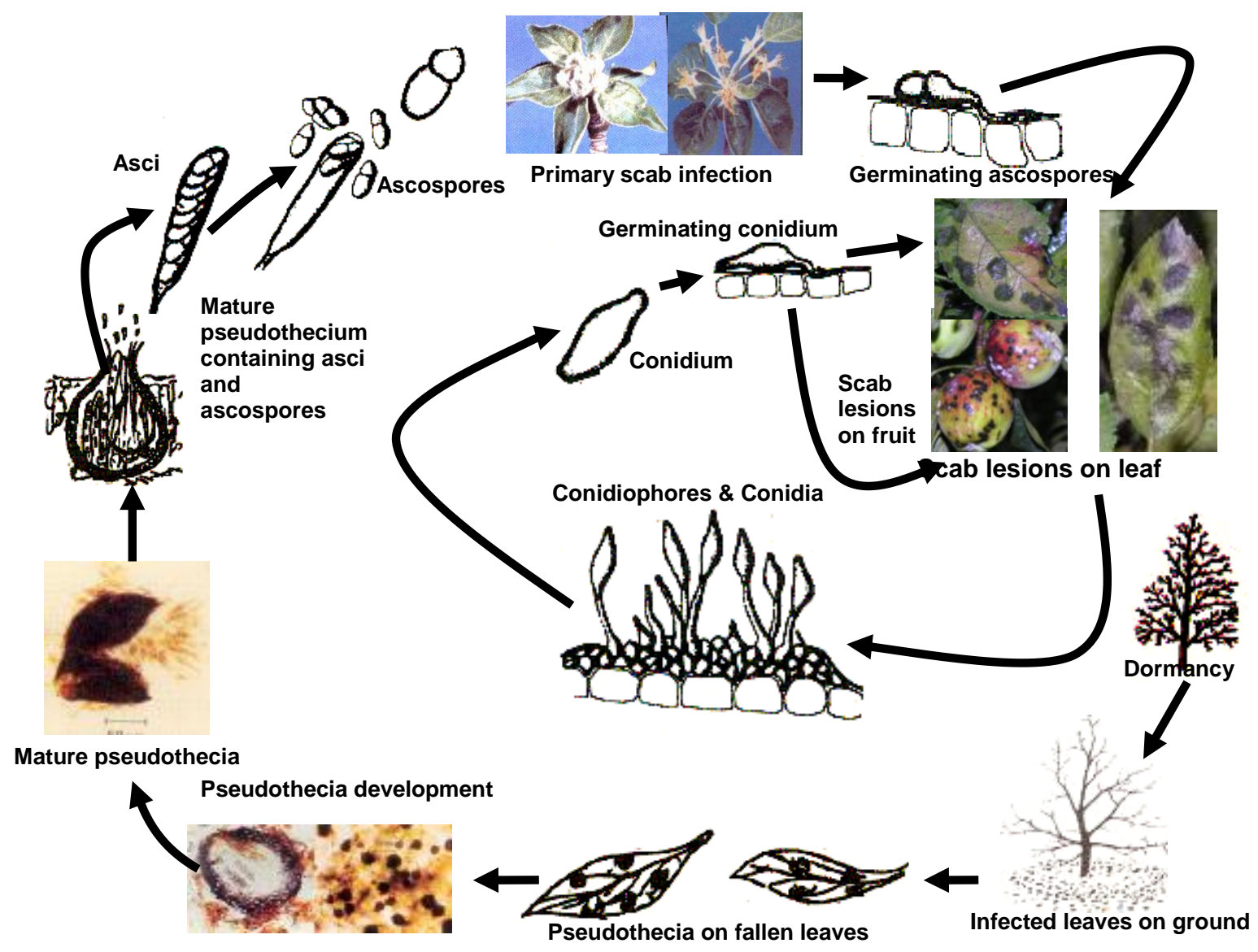

The mycelium of the fungus at first is light in color, but later turns brownish in the host tissue. In young leaf lesions, the mycelium develop radially in branched ribbons of hyphae but in older leaves and on fruits the mycelium strands are compact, thick and in several superimposed layers. In living tissue the mycelium is located only between the cuticle and the epidermal cells and produces short, erect and brownish conidiophores which successively give rise to several, one or two-celled, reddish brown Fusicladium type conidia of variable shape. In dead leaves the mycelium grows through the leaf tissue, and extends into mesophyll where it gives rise to primordia which becomes the perithecia on the leaves but Luttrell (1973) identified the ascocarp of $V$. inaequalis as a pseudothecium. The pseudothecia are embedded in the tissue of the leaf, but they protrude through the cuticle and are observed as small, black, dome - shaped 'pimples'. They are usually visible to the naked eye.

The mature pseudothecia resulting from the fertilization of ascogonia and antheridia are dark brown to black with slight beak and ostiolate openings. Inside the pseudothecium 70 - 100 asci are formed, each containing eight ascospores. Each ascospores consists of two cells of unequal size, which are hyaline at first, but on maturity these turn brown.

\section{Disease cycle}

The fungus over wintered in the diseased leaves fallen on the orchard floor. During autumn, the fungus begins to form tiny 
fruiting bodies, which are embedded in the leaves near the surface, but they protrude through the cuticle and are observed within 4 weeks after leaf fall. Pseudothecia were described by Wallace (1913) as spherical or subspherical fruiting bodies $90-160 \mu \mathrm{m}$ in diameter with a somewhat beak-like projection at the ostiole that is surrounded, at times, with six or more simple, tapering bristles $25-75 \mu \mathrm{m}$ in length. The pseudothecium is initiated in the apex of a hypha that is indistinguishable from vegetative hypha.

The hypha develops a helical growth that enlarges and forms an ascogonium surrounded by an initial of a pseudothecial wall. The trichogyne is produced that protrudes from the pseudothecium. The apex of another hypha develops into a well differentiated, multinucleate antheridium. The two organs come in contact, a pore is formed in the wall, and, finally, the male nuclei pass through the trichogyne into the asscogonial coil and pair with the female nuclei of the ascogonium. No nuclear fusion occurs in the ascogonium.

An ascogenous hyphae originated when a bitunicate hyphal cell arose as lateral outgrowth of the ascogonium and formed a crozier. The two nuclei than occupied the crozier, where they began a simultaneous mitosis. A crozier at the tip of an ascogenous hyphae forms a uninucleate terminal cell and a binucleate penultimate cell. The nuclei fuse almost as soon as the penultimate cell is formed to give the primary nucleus of the ascus, and the cell then grows into a young ascus. The ascus elongates and undergoes meiotic followed by mitotic division. The meiotic division reduces the number of chromosomes per nucleus. The mitotic division occurs rapidly soon after and there is a comparatively short lapse of time between the four-nucleate and eight nucleate stages.
Following a distinct incubation, these pseudothecia in the presence of moisture continue to grow during the warm periods in the winter and early spring but rapid growth and ascospores maturation occur with the resumptions of favourable weather for growth and development of the host. Pseudothecia and asci do not mature simultaneously. On the single leaf nearly 2,000 pseudothecia are present, each having 100 to 150 asci with a total load about 2 million ascospores. The two -celled ascospores that result then elongate to form matured ascospores comprised of two uninucleate cell of unequal size. These ascospores continue to mature and are discharged over a period of 5 to 9 weeks. Some may shed the ascospores before the apple buds start to open in the spring, however, most of the ascospores in the pseudothecia mature and discharged usually occurs between pink and the full bloom stage of apple bud development. Most of the ascospore have matured by the end of bloom. Matured ascospores are discharged into the air during period of rain. In daylight, discharge usually begins within 30 minutes after the start of the rain and is largely completed within 3 to 6 hours. When rainfall begins at night, discharged is often delayed until daybreak, although significant night discharge can occur under some conditions. Ascospores discharge may continue for 3 to 4 week after petal fall. The maturity of ascospores is slow at $4-7^{\circ} \mathrm{C}$ but it is faster at $12-16^{\circ} \mathrm{C}$, with an optimum at $18^{\circ} \mathrm{C}$ but beyond $20^{\circ} \mathrm{C}$ their formation ceases.

Ascospores are blown to nearby trees by wind currents, and they germinate in a film of water on the surface of leaves and fruit. If surface wetness continues long enough at prevailing temperature, growth from the germinated spore penetrates and infects the organs just beneath the outer cuticle. Thus, for infection the spores must be continuously wet for $28^{\text {th }} \mathrm{h}$ at $6^{\circ} \mathrm{C}$, for $14^{\text {th }} \mathrm{h}$ at $10^{\circ} \mathrm{C}$, for $9 \mathrm{~h}$ at $18-24^{\circ} \mathrm{C}$ 
and for $12 \mathrm{~h}$ at $26^{\circ} \mathrm{C}$. Typical lesions appear within 8 to 21 days later depending on temperature, although long period of low humidity can delay their development.

Upon germination as an apple leaf or fruit, the ascospores produces a disc like asppressorium from which a slender mycelial tube pierces the cuticle, and after developing into a hypha of normal diameter, it grows between the cuticle and the outer cell wall of the epidermal cells. For a few days after infection, the epidermal cells show no injury at all, but by the time the lesion appears these cells show a gradual depletion of their contents, and they eventually collapse and die. Soon the palisade and later the mesophyll, cells exhibit the same reactions, while the fungus still remains largely in the subcuticular position. With the establishment of mycelium in the host, it produces enormous number of conidia which are pushed out word by rupturing the cuticle and form olive-green, velvety scab lesions within 8 to $15^{\text {th }}$ days. Conidia remain attached to the conidiophores in dry weather, but upon wetting during the rains these are easily detached, and may be washed down or blown away to other leaves or fruit on which they germinate and cause infection in the same way ascospores do.

Additional infections by conidia continue throughout the growing season following a rainy period of sufficient duration. Conidia are then the principle source (up to $1,00,000$ conidia in each leaf lesion) involved in the build-up of the disease during the summer and early autumn, and again in the fall and in frequent or nearly absent in the dry hot summer weather. Atmospheric humidity up to 90 per cent and temperature around 16-to $20^{\circ}$ $\mathrm{C}$ favour conidial production. Many such conidial cycles occur which are responsible for disease epidemics throughout the growing season. Late infection on the leaves provide overwintering inoculums to produce the pseudothecial initial, thus completing the life cycle of the fungus (Fig. 6).

\section{References}

Aderhold, R. 1896. Fusicladien unserer Obstbaume. Tail I. Landow. Jahrb. 25:875-914.

Aderhold, R. 1897. Revision der species Venturia chlorospora, inaequalis und ditricha autorum. Hedwigia 36: 81

Clinton, G. P. 1901. Apple scab. III. Agric. Exp. Stn. Bull. 69: 47 pp. Gupta, G. K., and Lele, V. C. 1980. Role of Urea in suppression of ascigerous stage, and comparative in-vitro efficacy of fungicides against apple scab. Indian $J$. Agric. Sci. 50: 167-173.

Gupta, G. K. and Lele, V. C. 1980 a. Prevalence, distribution and intensity of apple scab in Kashmir valley. Indian $J$. Agric. Sci. 50: 45-50.

Gupta, G. K. and Lele, V. C. 1980. Role of urea in suppression of ascigerous stage and comparative in vitro efficacy of fungicides against apple scab. Indian $J$. Agric. Sci. 50: 167-173.

Kiett, G. W. 1953. Scab of apples. Pages. 646-652 In: Plant Disease, The Yearbook of Agriculture. A. Stefferud, ed. USDA, Washington, D. C 940 pp.

Luttrel, E. S. 1973. Loculoascomycetes. The Fungi, G. C 135-219 Ainsworth, F. K. Sparrow, and A. S Sussman, eds.

Singh, K.P. and Kumar, J 2005. Integrated pest mangment of apple scab GBPUA\&T Tech. Bulletin $\mathrm{p} 34$.

Singh, K.P., Singh, Amitabh and Kumar, J. 2005. Reduction in the ascospore inoculum of Venturia inaequalis on apple through fungal antagonists. Second Global Conference "Plant Health-Global Wealth" organized by Indian Society of Mycology and Plant Pathology and MPUAT, Udaipur from 
November 25-29, 2005, SX-P64, p 200. [J. Mycol. Pl. Pathol. 35: 543]

Srivanesan, A. and Wallar, J. M. 1974. Venturia inaequalis: 401 In: CMI Descriptions of the pathogenic Fungi and Bacteria. Commonw. Mycol. Inst., Assoc. Biol., Kew, Survey, England. 2 pp.

Thakur, V. S. and Sharma, R. D. 1999. Effect of urea on microbial degradation of apple leaf litter and its relationship to the inhibition of pseudothecial development of Venturia inaequalis. Indian J. of Agricultural Science. 69: 147-151.

Thakur, V. S. and Xu, Xiangming. 2004. Integreted Apple orchard Management. A Technology Book for Farmers. Regional Horticulture Research Station, Mashobra, Himachal Pradesh.

Wallace, 1913. Scab disease of apples. N. Y. Agric. Exp. Stn. Bull. 335 pp.

Wallroth, F. G.1833. Cladosporium dendriticum. Fl. Crypt. Germ. 1:169.

\section{How to cite this article:}

Prasad R. K., K. P. Singh, R. K. Gupta and Kumar J. 2018. Symptoms, Etiology and Disease Cycle of Apple Scab in Harsil, Gangotri Fruit Belt, Uttarakhand, India. Int.J.Curr.Microbiol.App.Sci. 7(11): 3554-3565. doi: https://doi.org/10.20546/ijcmas.2018.711.404 